\title{
EXPLORING ISLAMIC PEER-TO-PEER LENDING FOR THE UNBANKABLE
}

\author{
Rizqi Umar Al Hashfi ${ }^{\text {, Alyta Shabrina Zusryn² }}$ \\ 'Centre for Research in Islamic Economics and Business, Faculty of Economics and Business, \\ Universitas Gadjah Mada \\ ${ }^{2}$ Faculty of Economics and Business, YARSI University \\ Email: rizqiumar5@gmail.com(correspondence author)
}

\begin{abstract}
Increasing internet penetration and technology-savvy generation in Indonesia can be an opportunity for high-tech businesses. Those are driven by the significant growth in the number of borrowers and lenders at the peer-to-peer (P2P) marketplace that provides alternative funding for small and medium enterprises (SMEs). The presence of shariacompliant P2P providers offers alternatives for both borrowers and financiers who concern about Islamic values. Our work aims to discuss the role of sharia P2P lending on improving people's welfare in Indonesia. By observing $26 \mathrm{P} 2 \mathrm{P}$ platform providers, we conclude that the sharia P2P providers are the potential to be developed. The applications of Islamic value technological advancements, which are the prohibition of interest, transparency, and a sophisticated credit scoring system, enable the unbanked population to access financial service, especially lending. However, the sharia platforms do not offer the redemption mechanism for financiers who take their money back early. Therefore, we also propose an integrated scheme for sharia P2P platforms.
\end{abstract}

Keywords: Islamic Finance, Peer-to-peer, Indonesia, Technology 


\section{Introduction}

The Islamic finance industry has been proliferating in Indonesia. Muslim populations drive that. However, in terms of financial inclusion and literacy, the Islamic finance industry is relatively low. The National Financial Literacy and Inclusion Survey in 2016 reported that compared to the conventional financial literacy and inclusion index, which is $29.66 \%$ and $67.82 \%$, respectively, the sharia financial literacy index was around $8.11 \%$ and the Islamic financial inclusion index was $11.06 \%$ (OJK 2016).

Knowledge and adoption of Islamic financial product are relatively low as the industry tend to expand on the retailer and corporation (BAPPENAS 2016). Furthermore, Islamic microfinance institutions focus on serving the lower-middle and the lower-income people who mostly are not bankable. On the one hand, they face inadequate capital, which makes it challenging to expand their business efficiently. On the other hand, they must compete intensely with conventional banks widening their market scope to the micro sector. For reality, it needs a breakthrough which can increase literacy and inclusion on Islamic financial product.

Based on a survey, the financial technology (henceforth we call fintech) is one of the most influential factors changing dramatically global financial institutions (KPMG 2017). As part of fintech, peer-to-peer lending (P2P) development is increasing rapidly in some countries such as America and China (Galaski 2015). Efficiency and flexibility support the development of P2P finance companies (Guo et al. 2016). Some previous studies offered an overview of how technology shapes financial practice and then industry. Big data analysis can quickly determine the criteria for financing feasibility (Dorfleitner et al. 2016; Duarte, Siegel, and Young 2012; Gao and Lin 2015; Han et al. 2018; lyer et al. 2016; X. Wang et al. 2013). This innovation is widely applied in P2P marketplace providers in several countries, including Indonesia. The P2P platform facilitates borrowers and financiers to meet and negotiate directly in a marketplace via the internet (Wang et al. 2015).

High internet penetration and increased technology-savvy generations are the potential to contribute to fintech business in Indonesia, especially P2P Lending. According to the Financial Services Authority (OJK), 40 companies have been registered until June 2018. Most offer debt-based P2P products, and few offer sharia P2P products. Besides, the sharia P2P scheme becomes the central issue in line with the massive growth in the fintech industry in the Organization for Islamic Cooperation (OIC) countries (IFSB 2017).

Some fintech companies, such as Beehive (United Arab Emirates) and Liwwa (Jordan), offer sharia P2P products under the murabahah and tawarruq commodity schemes. Although the scheme is popular in some countries such as Malaysia, Saudi Arabia, and the United Arab Emirates and the National Sharia Council of MUI issued a fatwa NO: 82 / DSN-MUI / VIII / 2011 about those schemes, it is still limited in infrastructure and institution. Therefore, first, our work is intended to discuss how to shape a sharia-compliant P2P financing scheme. Second, in accord with their contribution to Indonesia's economy, small and medium enterprises often deal with less access to financial services, especially lending, and are classified as a highly risky segment. However, we also adopt a scheme to mitigate all risks in sharia P2P platforms. Last but not least, liquidity is the main problem faced by financiers who want to take their money back early to propose a redemption scheme. By applying recommendations and provisions launched by National Sharia Council, we expect that our work subscribes to ideas on developing a sharia-compliant P2P platform for embracing the unbanked population in Indonesia.

\section{Research Methods}

We use a literature study and descriptive analysis by observing firms' websites, providing the P2P marketplace in Indonesia. There are 63 firms as of June 2018 registered with the Financial Services Authority. By purposive sampling, we have 26 firms that disclose information regarding main target and product, financial transaction, and risk mitigation. A list of companies can be seen in Appendix 1. In addition to observing, our study also reports data related to financial indicators overviews from the Financial Services Authority from January to May 2018. 


\section{Result and Discussion}

The discussion in this study will discuss the concepts and some empirical studies of peer to peer financing (P2P) in Indonesia. We also show some practical aspects of P2P financing in Indonesia. Furthermore, in the end, we explain how the sharia P2P financing scheme is applied by adopting a contract in Islamic Financial Institutions.

\subsection{P2P Lending Financing: Concepts and Empirical Studies}

Peer to peer (P2P) financing is a debt crowdfunding that uses the internet to collect funding from various parties (Li et al. 2015). In the P2P model, the lender acts as a creditor so that the financing has a certain period, and there are interest obligations. Meanwhile, in equity crowdfunding, financiers can ask equity users to buy their shares or allow the new potential ones to buy their shares.

Unlike bank lending, P2P financing only provides a marketplace to connect financiers and fund borrowers (Hui Wang, Greiner, and Aronson 2009). Launched by ZOPA for the first time in 2005, the platform has well adopted around the world (Chen et al. 2016). Concerning that, Institutions, offering the platform, expand their stakeholders, including financiers, borrowers, banks, communities, and government.

Like other financing platforms, P2P also has specific risks, namely, intermediation and transparency (Li et al. 2015; Huaiqing Wang et al. 2015). Those risks can be mitigated by synchronizing information between financiers and borrowers. The higher the asymmetric information they face, the greater the cost of capital borrowers have to be borne (Asri 2015). Therefore, the cost of capital is influenced by asymmetric information due to errors in choosing investments or adverse behavior of capital users.

By utilizing technology, big data is useful to manage financing risk in P2P companies. Big data can be collected from the number of online transactions, social media, endorsements, and the information's completeness. More and more information determines the feasibility of financing (Duarte, Siegel, and Young 2012; lyer et al. 2016; X. Wang et al. 2013) and minimizes the cost of funds (Freedman and Jin 2017; Q. Zhang, Chen, and Cai 2008). Thus big data can reduce asymmetric information.

Besides, information about the loan (credit score) also determines the default risk so that it affects investors' required rate of return. Dorfleitner (2016) compared the two leading P2P platforms, Smava and Auxmoney, based in Germany. Smava is stringent in disposing of for loans to guarantee loan quality while Auxmoney does not apply credit assessments but emphasize on voluntary information (for example, loan proposals). He concluded that although financiers consider voluntary information, credit rating plays a more significant role.

Besides disclosing information about business networks, endorsements, and loan quality, joint liability schemes can be a solution to the asymmetric information problem. In the schemes, gathering information from group members can be used to provide solutions to asymmetric information problems (Ghatak 2000). Therefore, loans without collateral can be made.

\subsection{P2P Lending Company Practices in Indonesia}

In line with the rapid expansion of the P2P business, the Financial Services Authority issued regulation no. 77 /POJK.01/2016 about Information Technology-Based Lending and Borrowing Services. The fintech companies registered in Indonesia as of June 2018 totaled 63 companies. Most of the fintech business models are in the form of P2P marketplaces, which provide a place for borrowers to raise funds and for financiers to invest in various types of businesses. Because the contract is debts, the borrower must return the money and pay interest to the financiers. However, some companies offer forms of equity crowdfunding. The scheme offers a portion of shares to angel investors to suit the start-up and small-medium enterprises.

The number of borrowers and lenders in the P2P Lending business in Indonesia increased from January to May 2018. Those were dominated from Java Island in early 2018 , the number of lenders reached 87,728 accounts and increased every month, so do outside Java and abroad. The growth of foreign lenders from January to May was $34.14 \%$, from 1,781 to 2,389 accounts. Therefore, we conclude that the presence of P2P lending can attract foreign capital inflow.

Table 1. Number of Lenders and Borrowers in January-May 2018 


\begin{tabular}{lccccc}
\hline & \multicolumn{5}{c}{ The Year of 2018 } \\
\cline { 2 - 6 } Description & January & February & March & April & May \\
\hline Accumulated Number of Lenders (Account Unit) & & & \\
\hline Lender from Java & 87.728 & 101.543 & 115.050 & 128.387 & 158.512 \\
Lender from out of Java & 26.430 & 24.660 & 28.865 & 31.809 & 38.638 \\
Lender from Overseas & 1.781 & 1.916 & 2.050 & 2.177 & 2.389 \\
Total & 115.939 & 128.119 & 145.965 & 162.373 & 199.539 \\
\hline Accumulated Number of Borrowers (Account Unit) & & & \\
\hline Borrower from Java & 300.785 & 501.947 & 927.837 & 1.323 .250 & 1.665 .219 \\
Borrower from out of Java & 29.369 & 44.747 & 104.939 & 153.532 & 185.413 \\
Total & 330.154 & 546.694 & 1.032 .776 & 1.476 .782 & 1.850 .632 \\
\hline
\end{tabular}

Financial Service Authority (OJK), 2018

Based on Table 1, in the loan demand side, the number of borrowers at P2P Lending in Indonesia, both from Java and Outside Java, increases significantly from January to May by $460.54 \%$. The number of borrowers in January was 330,154 accounts, and in May, it was $1,850,632$ accounts. Borrowers dominated this significant growth from Java, namely more than $90 \%$ of P2P lending borrowers in Indonesia, whereas around $10 \%$ are borrowers from outside Java.

P2P lending businesses that provide loans online provide alternative funding for micro, small, and medium businesses. However, the financial industry is still at a developmental stage because online loans have a higher risk than other financial services. One of the risks faced is a high default risk because it has difficulties in effectively identifying bad loans (Y. Zhang et al. 2017). Based on data obtained from the Financial Services Authority in Tabel 2, it is recorded that the value of the ratio of bad loans to P2P lending has decreased.

Table 2. Average Quality of P2P Lending Loans in January-May 2018

\begin{tabular}{lccccc}
\hline & \multicolumn{5}{c}{ The Year of 2018 (in percent) } \\
\cline { 2 - 6 } Average Loan Quality & January & February & March & April & May \\
\hline Performing Loan Ratio (to 30 days) & 94,65 & 97,62 & 98,65 & 98,72 & 98,18 \\
Less performing Loan Ratio (30 days & & & & & \\
to 90 days) & 4,07 & 1,60 & 0,81 & 0,75 & 1,18 \\
Default Loan Ratio (>90 days) & 1,28 & 0,78 & 0,55 & 0,53 & 0,64 \\
\hline
\end{tabular}

Financial Service Authority (OJK), 2018

Table 2 shows that the performing loan ratio in Indonesia's P2P lending business is quite high, ranging from $94.65 \%$ to $98.18 \%$. Besides, the default loan ratio from January to May 2018 decreased from $1.28 \%$ to $0.64 \%$. It shows that P2P lending seems relatively smooth, while the demand for loans increased rapidly. Credit assessments in P2P Lending use big data to dispose of whether the borrower is feasible or not to get a loan. Therefore, technology usage in valuing credit can mitigate the risks that occur in P2P lending.

Twenty-six companies were proving P2P platforms we could observe until May 2018, the results of which can be seen in the Appendix section. We discuss the observational study of those companies registered with OJK is as follows.

\subsection{Main Target and Product}

Most of the capital users are SMEs from several sectors, such as communication (mobile phone outlets), agriculture, maritime, and fisheries. Some P2P providers offer funding schemes for consumers and students. The primary funding purposes are business expansion and factoring. The first could be in the form of goods/services procurement or additional capital. In the factoring contract, invoices can be transferred to other parties or collateral to get cash. Some P2P companies offer redemption scheme for financiers then they could convert their receivable accounts into cash. However, as far as we could observe, the scheme has not 
been clearly explained. Meanwhile, other products are multi-finance services such as financing for health, education, and childbirth

\subsection{Financial Transaction}

About transactions and payment systems, most P2P companies provide virtual accounts. However, there is a company, PT Mitrausaha Indonesia Group, establishing custodial cooperation with a formal bank, Bank Sinarmas. The presence of a custodian bank can minimize asymmetric information because it can ensure P2P companies do not misuse that lender funds. Like unit trust products, a custodian bank guarantees that investment managers will put on money under the prospectus. Also, every transaction is made through a custodian Bank so as it would increasingly protect financiers and borrowers.

\subsection{Risk Mitigation}

The risk faced by financiers in debt contracts is default due to the asymmetric information, so risk mitigation must be applied to all financial institutions, including P2P companies. Many of them in Indonesia use credit scoring to assess loan worthiness. Before borrowers and financiers meet and negotiate in the marketplace, P2P providers value investment prospects by utilizing big data regarding salary slips, electricity bills, online shopping history, social media networks, the number of endorsements, and photos. Then, the credit assessment is continued with ranking based on the risk of default. The higher the risk, the higher the rate of return expected by the financiers, the higher the interest rate charged to the borrower.

In addition to analyzing using technology, some P2P companies also conduct surveys directly to borrowers. To ensure that financier's funds are secured, some companies apply protected funds scheme by utilizing insurance services and requiring collateral. For example, PT Lunaria Annua Teknologi implements protected funds by allocating profits to create a protection fund so that it can reduce financier losses if any borrower defaults. Investree has also established a partnership with one of the insurance companies, namely Zurich Topas Life. In the matter of that, the borrowers will get insurance protection. The collateral requirement is also still used by some P2P companies. The collateral can be in the form of bills/invoices, equipment, motor vehicles, land and buildings, jewelry, stocks, or securities, and its value is inversely proportional to risk and interest rates.

Besides, utilizing technology, surveys, insurance, and collateral requirement, another risk mitigation scheme is a joint liability system. One of the P2P companies implemented this scheme was PT Amartha Mikro Fintek. This model is applied to a group of borrowers who apply for financing. If there is, at least, a member who fails to pay, then it has to be borne by all members.

\section{Models and Applications for Sharia P2P Financing in Indonesia}

Our observational study in P2P financing practices in Indonesia shows that financiers and capital users, such as companies, groups, and individuals, can diversify investments and seek funding. The partnership can be business-to-business (B2B), business-to-costumer (B2C) or customer-to-costumer (C2C) form. Some P2P providers offer a redemption mechanism as in mutual funds, but the mechanism is not explained in detail.

Based on the Indonesian Sharia Fintech Association database, many P2P companies apply sharia principles, including e-funding, ethis crowd, capital boost, syarQ, syarfi, natural, ammana, qasir, and Islamic sharia, and sharia funds. However, in June 2018, there were only two sharia-compliance P2P companies registered with the Financial Services Authority (OJK), Ammana, and the Dana Syariah. Also, there is a company that offers Islamic financing products, Investree. One of sharia P2P lending companies, the Dana Syariah, implemented a profit-sharing contract to finance property business. Based on OJK regulation number 77 / POJK.01 / 2016, Dana Syariah uses the virtual account to ease the settlement process and use credit scoring to mitigate the probability of default

Besides, the company offering Islamic invoice financing products is PT Investree Radhika Jaya. In general, invoice financing arises from a business-to-business partnership in the procurement of goods and services. For example, there are two companies ( $A$ and $B$ ) entering into a procurement contract. Meanwhile, there is party $C$ as a financier. The " $A$ " is procuring goods to the " $B$ " and issues a bill (invoice) on behalf of the " $B$ ". Then, the "B" must pay the invoice for 30 days. Because the " $A$ " needs money soon, it guarantees the invoice to and gets 
a loan from the " $\mathrm{C}$ " in the amount of invoice value. At the maturity date, the "B" pays the bill to the "A". Finally, the " $A$ " repays the debt, including interest to the " $\mathrm{C}$ ". Due to the presence of interest, the platform does not comply with sharia principles

For the prohibition of interest-based transactions, Investree innovates with referring to the MUI DSN fatwa No. 67 / DSN-MUI / III / 2008 about Sharia Factoring and a recommendation letter from DSN-MUI, Letter Number U-492 / DSN-MUI / VIII / 2017. It requires only invoices from large firms or institutions (multinational, go public, and government agencies) and do not conflict with sharia (other than cigarettes, liquor, illegal drugs, pigs, gambling, prostitution, hotels that are not yet sharia, and activities that contain speculation) accepted. Furthermore, it is used shariah contracts (akad), namely, Qardh and Wakalah Bil Ujrah. Given our previous example, the " $C$ " lends the amount of money to the "A" by Qardh contract. At the same time, the " $\mathrm{C}$ " is entrusted with the mandate of the " $\mathrm{A}$ " (wakalah) to save the invoice. After the " $\mathrm{B}$ " pays the bill, the " $C$ " is entitled to get a fee (ujrah) from the "A".

The benefit offered in this sharia invoice loan is no interest charge but only administrative fees. Because all transaction is made and recorded in the online P2P system, there is no hidden costs and procedures. Compared to an Islamic microfinance institution, sharia P2P lending can quickly help borrowers obtain funding.

Most P2P still have conventional schemes, namely usury, uncertainty (gharar), gambling (maysir), and the possibility of funding used in non-halal sectors such as (cigarettes, liquor, prostitution, etc.). The presence of sharia P2P lending institutions described in the previous discussion is expected to provide alternative funding for people who pay attention to sharia principles to get funding quickly and easily. However, sharia P2P lending is less flexible for financiers to get their money back by selling investment shares in businesses. Therefore, in addition to explaining the results of observations on conventional and sharia P2P lending, this study also offers the new sharia P2P financing. We refer to National Sharia Council Fatwa, Indonesian Ulema Council (DSN-MUI), OJK Regulations, and Capital Market Law to create an integrated scheme for sharia P2P financing.

Figure 1. An integrated sharia P2P financing scheme

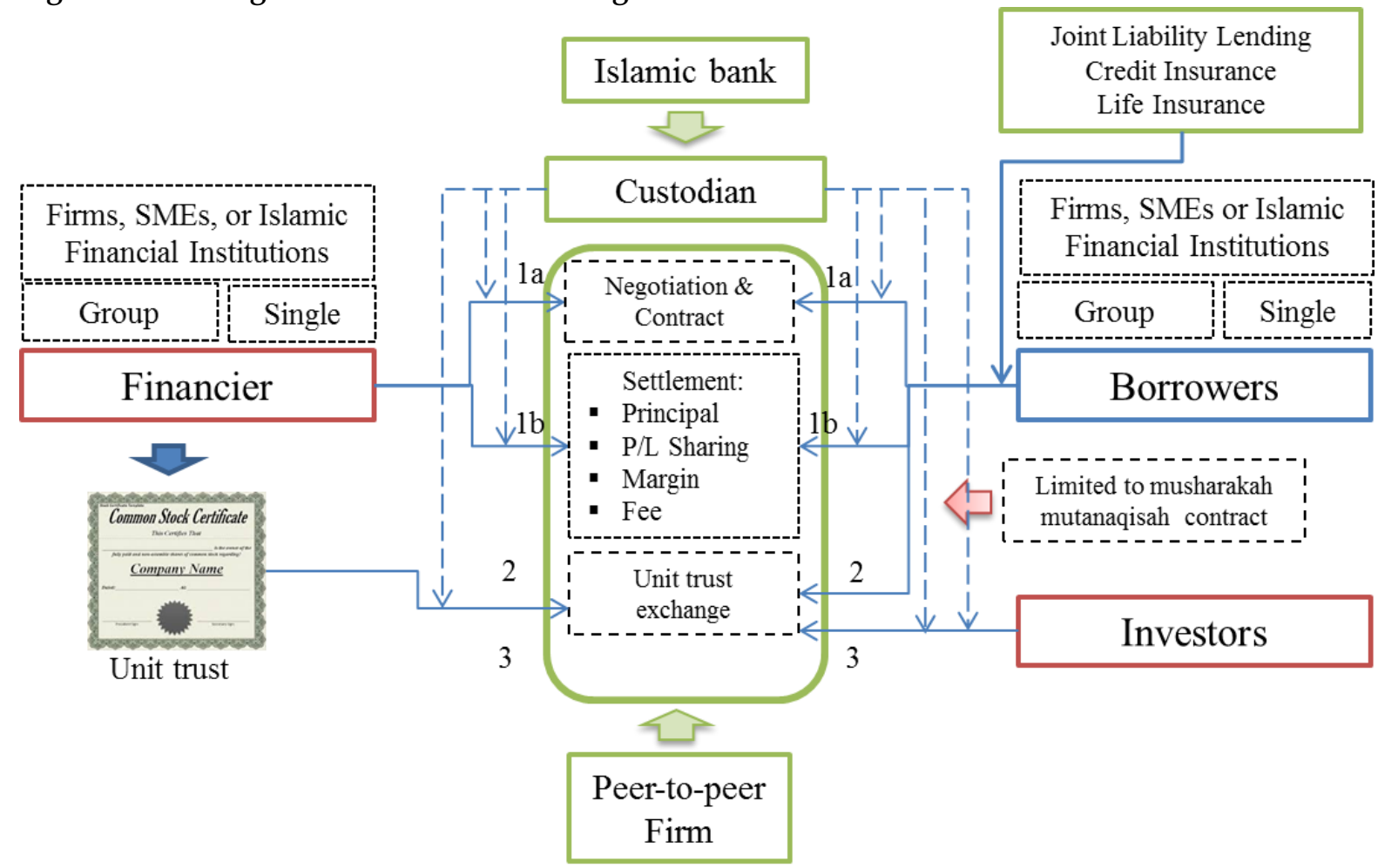

The P2P companies act as both service organizers, providers, and guarantors, while Islamic banks are only guarantors. As organizers, P2P companies have to present information and guarantee transaction security. The information includes credit scores, equivalent rate of return in Islamic bank for all financing products, and economic indicators and data. Islamic 
banks also guarantee that P2P companies do not misuse any money transferred through a virtual account. In this case, the Islamic bank acts as a custodian bank. Financiers enter into the Kafalah bil Ujrah contracts along with the P2P providers and Islamic banks. Based on DSN fatwa No. 11 / DSN-MUI / IV / 2000, the kafalah is a guarantee given by a guarantor (Kafiil) to a third party to fulfill the obligations of a second party or the being covered (Makfuul 'Anhu Ashil). The guarantor is permissible to receive a reward (Ujrah) as long as it is not burdensome. We explain the sharia P2P scheme as follow:

1) Funding Product Mechanism (schemes la and $1 \mathrm{~b}$ figure 1)

Sharia P2P companies have the duty and authority to provide marketplace and information provider services using technology. The marketplace offers equity-based and debt-based financing in various sharia-compliant businesses, especially small-medium enterprises (SMEs). SMEs can propose a business plan to P2P companies. Types of businesses have distinguished funding schemes and also imply different contracts.

If it relates to the procurement of goods/services, it can use a purchasing mechanism (such as Murabahah, Salam, or Istishna) following fatwa 110 / DSN-MUI / IX / 2017 about the sale and purchase agreement (DSN 2017a). The difference between the three contracts is based on the delivery of money and goods. Based on fatwa 111 / DSN-MUI / IX / 2017 about murabaha, the delivery of goods is at the beginning contract while money can be paid in cash, tight, or installments (DSN 2017b). It is different from Salam and Istisna, in which goods are delivered at the end. In the Salam, payment is made in cash, but in the Istishna, it is based on buyer and seller agreement.

To determine margins, it is applied to an auction scheme in which sellers and buyers bargain with each other. In the term of Islamic contract, it is called Bai Musawamah. Like financing products in Islamic financial institutions (IFIs), financiers act as a representation of borrowers to buy goods by the Wakalah contract. One of the many aspects that differ from applications in IFls is using three contracts (Bai Musawamah, Bai Murabahah, and Wakalah) in a transaction.

The contracts used for multi-service products are Wakalah, Kafalah, Hawalah, Qardh al Hasan, ljarah, or ljarah Muntahiya Bi Tamlik (IMBT). A P2P company in Indonesia has offered sharia factoring (Hawalah) products by utilizing large companies' invoices. The mechanism uses three contracts, namely, Hawalah, Qardh al Hasan, and Wakalah bil Ujrah. Based on practice in the LKS, factoring is applied to customers who want to take over from conventional to sharia banks. Factoring can also be applied to P2P schemes. For example, a businessman proposes a mortgage takeover financing at a conventional financial institution (CFI) worth IDR 200 million to financiers by the Qardh contract. After they agree to finance the factoring contract, the entrepreneur receives the amount of money from financier and pay off all his debt to CFI subsequently so as the house belongs to him and the receivable account goes to financiers. Then, the businessman sells his home to financiers worth IDR 200 million to repay his obligation recorded in the Qardh contract. Then, by the IMBT contract, financiers lease the house back to the businessman under the condition that the businessman wholly owns the house at the end of the rental period. Due to using a lease contract, financiers are entitled to a fee (ujrah).

As for equity-based financing, the contract used is the Syirkah (Mudharabah, Musharakah, and Musyarakah Mutanaqisah). In the sale-and-lease mechanism we explain above, there are margins, cost of goods, and fees. Unlike the Syirkah scheme, the principle used is profit and loss sharing agreed between financiers and borrowers. The scheme is what distinguishes it from conventional P2P schemes. IFI uses the Syirkah contract to finance working capital and investment. In practice, the Musyarakah Mutanaqisah contract is used in mortgage financing (Sakti et al. 2017). Also, the Syirkah can be applied to P2P equity crowdfunding schemes.

For example, a start-up enterprise plans to offer a partnership to financiers by the equitycrowdfunding platform. P2P company conducts a feasibility study and credit scoring on the business. If it passes the screening, the enterprise can offer its shares to financiers in the marketplace. The contract used depends on the capital structure. If 100 percent of the capital comes from financiers, they use the mudharahah contract. If the company has some proportion of capital, then it uses the musharakah contract. Conceptually, if the project is profitable, profit will be divided based on the agreement. However, if the investment becomes lost, the losses borne to both parties based on the proportion of capital. Those provisions apply to either the mudharabah and or musharakah contract. 
In mortgage financing, the IFI can also use two contracts: the musyarakah mutanaqisah and the ijarah, so do P2P providers. For example, an employee plans to buy an apartment worth IDR 900 million but only has IDR 400 million. In order to meet the shortfall IDR 500 million, he applies for mortgage financing by the P2P scheme. After passing the screening and credit scoring, the employee bargain with financiers regarding the amount of compensation (Ujrah). Furthermore, their partnership continues to the joint project of housing procurement by musyarakah mutanaqisah contract for four years. In the contract, after the project is completed, the employee is required to purchase the ownership of the financiers in the apartment. He must also pay rent for the utilization of part of the buildings owned by the financiers.

2) Pre-maturity Liquidity Mechanism (schemes 2 and 3 figure 1)

In addition to providing an overview of sharia P2P schemes, this article provides a new idea about the redemption mechanism of financiers before the contract is due. Adopting a closedended mutual fund scheme, financiers can sell their participation units to the others or borrowers. However, scheme two is intended for the mudharabah, the musyarakah, and the musyarakah mutanaqisah contract. The transaction mechanism refers to the MUI DSN fatwa NO: 40 / DSN-MUI / X / 2003 about the Capital Market and General Guidelines for the Application of Sharia Principles in the Capital Market and MUI DSN NO: 80 / DSN-MUI / III / 2011 about the Application of Sharia Principles in Equity Securities Trading Mechanisms in the Regular Market of the Stock Exchange (DSN 2011).

The mechanism adopted from the two fatwas or recommendations is that every transaction must avoid usury (riba), obscurity (Gharar), speculation (Maysir), monopoly (Bai Najasy), and fake demand (Ikhtikar). Besides, the purchasing process is based on the bai musawamah, the auction. All transactions (payment, dividend, fee, and safekeeping unit participation) must go through sharia custodian banks.

For example, a financier entering an equity crowdfunding contract has an investment participation unit in a start-up business. The unit can be sold to other financiers. The price of shares determines the value of the enterprise in the marketplace. The amount of money received by the financier is the selling price after deducting the fee (ujrah) for Islamic banks and P2P providers. Another example is on mortgage financing by the musyarakah mutanaqisah contract, back to the case of an employee who applied for mortgage financing. The value of financier's ownership is agreed at the beginning of the contract so that it does not follow the market mechanism.

3) Risk Management of Sharia P2P Lending

According to many empirical studies and observations on several P2P companies in Indonesia, the risk of asymmetric information needs to be managed. The first step starts with identifying and measuring risk through credit scoring and managing risk in several ways, including diversification and insurance (Hanafi 2016). Some P2P companies have collaborated with Credit Guarantee Institutions and Life insurance. Some companies implement a joint liability system for SME financing.

The principle of sharia guarantee refers to the MUI DSN fatwa No: 74 / DSN-MUI / I / 2009 by the kafalah bil ujrah contract (DSN 2009). The objects guaranteed are liabilities or those not conflicting with sharia. Meanwhile, in the mudharabah and musyarakah contract, the guarantee principle refers to the fatwa of DSN MUI NO: 1055 / DSN-MUI / X / 2016 (DSN 2016). Regarding ensuring invested capital, the borrower is not required to fully pay off it, if it is not due to negligence; b) the financier may not ask the borrower to ensure invested capital by the financier; c) the borrower may guarantee at his will; and d) the financier may ask a third party to guarantee the invested capital.

Based on the two contracts, the guarantee involves financiers and borrowers while based on OJK Regulation No. 77 /POJK.01/2016, service users (financiers and capital users) and P2P marketplace providers must carry out risk mitigation. However, the procedure is not explained in detail. According to figh, some Islamic scholars say that "something that applies based on customs is the same as something that applies based on shariah as long as it does not conflict with sharia." Therefore, the guarantee mechanism in the conventional scheme in P2P platform can be adopted in sharia P2P by referring to the DSN fatwas

If sharia P2P providers use third parties such as Life Insurance and Credit Guarantee Institution, they must go to a sharia institution or ask a sharia guarantee product. However, if they choose to apply for the joint liability system, the mechanism should be based on the 
kafalah bil ujrah contract. In the agreed period, each member is obliged to pay a fee to the group leader for the joint guarantee of the financiers' obligation or mandate.

\section{Conclusion}

The development of a fintech platform, P2P financing, was a factor driving the revolution in the financial service industry. Technology usage in the platform is more efficient and flexible. One of the technological innovations applied in terms of credit scoring is big data analysis. The innovation was also applied to $25 \mathrm{P} 2 \mathrm{P}$ companies registered with financial service authority (OJK). Based on our observations on these companies, most offer debt-based P2P lending while there is only one company that offers sharia-based financing.

From the literature study and observation of 25 P2P companies, we explain that mitigating risks in $\mathrm{P} 2 \mathrm{P}$ companies varies, including credit scoring, collateral, joint responsibility, and others. The payment system mostly uses a virtual account, but there is only one cooperates with a bank in terms of custodians. Most offer debt-based P2P lending, and there are only three P2P companies that offer Islamic financing scheme with a variety of contracts offered. The benefits offered in sharia P2P financing are no interest and only administrative fees. Sharia invoice financing does not include hidden costs and procedures because the process is made online and based on a system developed by the sharia P2P providers. also compared to Islamic microfinance, sharia P2P providers can help borrowers obtain financing more quickly and easily

This article also proposes a sharia P2P financing model adopted from the implementation of sharia P2P registered with the Financial Services Authority. Our work's implications are expected to improve consumer protection and the welfare of both borrowers and financiers. By eliminating practices that are not under sharia and adopting several Islamic financial institution products, this article leads to a sharia P2P financing model. Some cases and applications in Islamic financial contracts are presented in this article-limitations of this article on the comparison of P2P financing schemes in several OIC countries. Further studies and research are needed on how to implement and compare in some countries to produce models that are practical and innovative.

\section{References}

[1](DSN), National Sharia Council. 2000. "National Sharia Council Fatwa NO: 11 / DSNMUI / IV / 2000 Concerning Kafalah."

[2]_. 2009. "National Sharia Council Fatwa NO: 74 / DSN-MUI / / 2009 Concerning Sharia Guarantee."

[3]_. 2011. "National Sharia Council Fatwa NO: 80 / DSN-MUI / III / 2011 Concerning the Application of Sharia Principles in Equity Securities Trading Mechanisms in the Regular Stock Exchange Market."

[4] - 2016. "National Shari'ah Council Fatwa NO: 105 / DSN-MUI / X / 2016 Concerning Guaranteed Return of Mudharabah, Musyarakah, and Wakalah Bil Istitsmar Financing Capital."

[5]_. 2017a. "National Sharia Council Fatwa NO: 110 / DSN-MUI / IX / 2017 Concerning the Sale and Purchase Agreement."

[6]_. 2017b. "National Sharia Council Fatwa NO: 111 / DSN-MUI / IX / 2017 Concerning Murabahah Sale and Purchase Agreements."

[7]Asri, Marwan. 2015. Behavioral Finance (Keuangan Keperilakuan). Ist ed. Yogyakarta: BPFE Publisher.

[8] Chen, Xiao hong, Fu jing Jin, Qun Zhang, and Li Yang. 2016. "Are Investors Rational or Perceptual in P2P Lending?" Information Systems and E-Business Management 14 (4): 921-44. https://doi.org/10.1007/s10257-016-0305-z.

[9]Dorfleitner, Gregor, Christopher Priberny, Stephanie Schuster, Johannes Stoiber, Martina Weber, Ivan de Castro, and Julia Kammler. 2016. "Description-Text Related Soft Information in Peer-to-Peer Lending - Evidence from Two Leading European Platforms." Journal of Banking and Finance 64: 169-187. 
https://doi.org/10.1016/j.jbankfin.2015.11.009.

[10]Duarte, Jefferson, Stephan Siegel, and Lance Young. 2012. "Trust and Credit: The Role of Appearance in Peer-to-Peer Lending." Review of Financial Studies 25: 2455-83. https://doi.org/10.1093/rfs/hhs071.

[11]Financial Services Authority (OJK). 2016. "2016 National Literacy and Financial Inclusion Survey." Otoritas Jasa Keuangan (OJK). 2016.

[12]Freedman, Seth, and Ginger Zhe Jin. 2017. "The Information Valve of Online Social Networks: Lessons from Peer-to-Peer Lending." International Journal of Industrial Organization 51: 185-222. https://doi.org/10.1016/j.jindorg.2016.09.002.

[13]Galaski, Rob. 2015. "Digital Disruption in Financial Services The Innovation Imperative." Deloitte Southeast Asia Financial Services Newsletter, 2015.

[14] Gao, Qiang, and Mingfeng Lin. 2015. "Lemon or Cherry? The Valve of Texts in Debt Crowdfunding." SSRN Electronic Journal. https://doi.org/10.2139/ssrn.2446114.

[15] Ghatak, Maitreesh. 2000. "Screening by the Company You Keep: Joint Liability Lending and the Peer Selection." Economic Journal 110: 601-31. https://doi.org/10.1111/1468-0297.00556.

[16] Guo, Yanhong, Wenjun Zhou, Chunyu Luo, Chuanren Liu, and Hui Xiong. 2016. "Instance-Based Credit Risk Assessment for Investment Decisions in P2P Lending." European Journal of Operational Research 249: 417-426. https://doi.org/10.1016/j.ejor.2015.05.050.

[17] Han, Jing Ti, Qun Chen, Jian Guo Liu, Xiao Lan Luo, and Weiguo Fan. 2018. "The Persuasion of Borrowers' Voluntary Information in Peer to Peer Lending: An Empirical Study Based on Elaboration Likelihood Model." Computers in Human Behavior. https://doi.org/10.1016/j.chb.2017.09.004.

[18] Hanafi, Mamduh M. 2016. Risk Management (Manajemen Risiko). Yogyakarta: UPP STIM YKPN.

[19] Islamic Financial Service Board (IFSB). 2017. Islamic Financial Services Industry Stability Report 2017. Kuala Lumpur: Islamic Financial Service Board (IFSB).

[20]lyer, Rajkamal, Asim ljaz Khwaja, Erzo F.P. Luttmer, and Kelly Shue. 2016. "Screening Peers Softly: Inferring the Quality of Small Borrowers." Management Science 62 (6): 1554-77. https://doi.org/10.1287/mnsc.2015.2181.

[21]KPMG. 2017. "Forging the Future: How Financial Institutions Are Embracing Fintech to Evolve and Grow."

[22] Li, Siming, Zhangxi Lin, Jiaxian Qiu, Roozmehr Safi, and Zhongyi Xiao. 2015. "How Friendship Networks Work in Online P2P Lending Markets." Nankai Business Review International 6 (1): 42-67. https://doi.org/10.1108/NBRI-01-2014-0010.

[23]National Planning and Development Agency (BAPPENAS). 2016. Indonesian Islamic Finance Architecture Plan (Materplan Arsitektur Keuangan Syariah Indonesia). Jakarta: Badan Perencanaan dan Pembangunan Nasional.

[24]Sakti, Ali, Androecia Darwis, Darsono, Enny Tin Suryanti, and Siti Astiyah. 2017. The Dynamics of Islamic Financial Products and Contracts in Indonesia (Dinamika Produk Dan Akad Keuangan Syariah Di Indonesia). 1st ed. Depok: Rajawali Pers.

[25]Wang, Huaiaing, Kun Chen, Wei Zhu, and Zhenxia Song. 2015. "A Process Model on P2P Lending." Financial Innovation 1 (3): 1-8. https://doi.org/10.1186/s40854015-0002-9.

[26] Wang, Hui, Martina Greiner, and Jay E. Aronson. 2009. "People-to-People Lending: The Emerging e-Commerce Transformation of a Financial Market." In 15th Americas Conference on Information Systems 2009, AMCIS 2009.

[27]Wang, Xubo, Defu Zhang, Xiangxiang Zeng, and Xiaoying Wu. 2013. "A Bayesian Investment Model for Online P2P Lending." Communications in Computer and Information Science. https://doi.org/10.1007/978-3-642-53959-6_3.

[28]Zhang, Qi, Xiao-hong Chen, and Shen-yuan Cai. 2008. "Empirical Study on the 
Relationship between Scale Discrimination and SMEs' Financing Behavior Based on the Data from Hunan SMEs." System Engineering 26 (10): 61-66.

[29]Zhang, Yuejin, Haifeng Li, Mo Hai, Jiaxuan Li, and Aihua Li. 2017. "Determinants of Loan Funded Successful in Online P2P Lending." Procedia Computer Science 122: 896-901. https://doi.org/10.1016/j.procs.2017.11.452. 
Appendix 1.

The following is a list of peer-to-peer (P2P) companies registered with the Financial Services Authority (OJK) until June 2018

\begin{tabular}{|c|c|c|c|}
\hline & Company & Website & Short description \\
\hline 1 & PT Pasar Dana Pinjaman & $\begin{array}{l}\text { https://p2p.danamas. } \\
\text { co.id/ }\end{array}$ & $\begin{array}{l}\text { Business model: P2P Marketplace. } \\
\text { The main target: small and medium business } \\
\text { Financial transactions: virtual account } \\
\text { Risk mitigation: not explained in detail }\end{array}$ \\
\hline 2 & PT Lunaria Annua Teknologi & https://koinworks.com & $\begin{array}{l}\text { Business model: P2P marketplace } \\
\text { The main target: small and medium business } \\
\text { (business, education, health financing } \\
\text { products). } \\
\text { Financial transactions: virtual account } \\
\text { Risk mitigation: assessment and ranking } \\
\text { using the Machine Learning method, life } \\
\text { insurance \& protected funds }\end{array}$ \\
\hline 3 & PT Danakita Data Prima & $\begin{array}{l}\text { https://www.danakita } \\
. c o m /\end{array}$ & $\begin{array}{l}\text { Business model: P2P marketplace } \\
\text { The main target: small and medium business } \\
\text { (only for the DKI Jakarta area) } \\
\text { Financial transactions: virtual account } \\
\text { Risk mitigation: credit scoring }\end{array}$ \\
\hline 4 & PT Amartha Mikro Fintek & $\begin{array}{l}\text { https://www.amartha. } \\
\text { com/ }\end{array}$ & $\begin{array}{l}\text { Business model: P2P marketplace } \\
\text { The main target: small and medium business } \\
\text { group } \\
\text { Financial transactions: virtual account } \\
\text { Risk mitigation: credit scoring system with } \\
\text { machine learning, joint liability, in } \\
\text { partnership with Credit Guarantee and Life } \\
\text { Insurance. }\end{array}$ \\
\hline 5 & $\begin{array}{l}\text { PT Mitrausaha Indonesia } \\
\text { Group }\end{array}$ & $\begin{array}{l}\text { https://www.modalku. } \\
\text { co.id/ } \\
\end{array}$ & $\begin{array}{l}\text { Business model: P2P marketplace } \\
\text { The main target: The main target (minimum } \\
\text { turnover of IDR } 20 \text { Million/month), invoice } \\
\text { financing. } \\
\text { Financial transactions: virtual account } \\
\text { (custodial agreement with Bank Sinarmas) } \\
\text { Risk mitigation: credit scoring }\end{array}$ \\
\hline 6 & PT Investree Radhika Jaya & $\begin{array}{l}\text { https://www.investree } \\
. \mathrm{id/} \\
\end{array}$ & $\begin{array}{l}\text { Business model: P2P marketplace } \\
\text { The main target: a) business (invoice, online } \\
\text { seller, sharia) b) individual/employee } \\
\text { (employee financing, working in a } \\
\text { company that cooperates with Investree, } \\
\text { types of financing: home renovation, } \\
\text { education, vacation, marriage, health). } \\
\text { Financial transactions: virtual account } \\
\text { Risk mitigation: credit scoring and ranking. }\end{array}$ \\
\hline 7 & $\begin{array}{l}\text { PT Pendanaan Teknologi } \\
\text { Nusa }\end{array}$ & $\begin{array}{l}\text { http://www.pendana } \\
\text { an.co.id } \\
\end{array}$ & $\begin{array}{l}\text { Business model: P2P marketplace } \\
\text { Main target: general } \\
\text { Financial transactions: virtual account } \\
\text { Risk mitigation: credit scoring }\end{array}$ \\
\hline 8 & $\begin{array}{l}\text { PT SimpleFi Teknologi } \\
\text { Indonesia }\end{array}$ & $\begin{array}{l}\text { https://www.awantun } \\
\text { ai.com }\end{array}$ & $\begin{array}{l}\text { Business model: P2P financing } \\
\text { Main target: general } \\
\text { Financial transactions: virtual account } \\
\text { Risk mitigation: not specifically explained }\end{array}$ \\
\hline 9 & PT Aman Cermat Cepat & https://klikacc.com/ & $\begin{array}{l}\text { Business model: P2P marketplace } \\
\text { Main targets: general (providing invoice } \\
\text { auctions), businesses (partnership-based). } \\
\text { Financial transactions: virtual account } \\
\text { Risk mitigation: credit scoring, survey }\end{array}$ \\
\hline 10 & $\begin{array}{l}\text { PT Mediator Komunitas } \\
\text { Indonesia }\end{array}$ & https://crowdo.co.id/ & $\begin{array}{l}\text { Business model: Peer-to-Business Investing } \\
\text { (P2B), Equity Crowdfunding, } \\
\text { Primary target: MSME (start-up business) } \\
\text { Financial transactions: virtual account }\end{array}$ \\
\hline
\end{tabular}




\begin{tabular}{|c|c|c|c|}
\hline & & & $\begin{array}{l}\text { Risk mitigation: Collateral, credit scoring, } \\
\text { ranking. }\end{array}$ \\
\hline 11 & $\begin{array}{l}\text { PT Akseleran Keuangan } \\
\text { Inklusif Indonesia }\end{array}$ & https://www.akselera & $\begin{array}{l}\text { Business model: P2P marketplace and } \\
\text { equity crowdfunding } \\
\text { Main targets: start-ups and SMEs; private } \\
\text { business entity, firm, CV, or PT. } \\
\text { Financial transactions: virtual account } \\
\text { Risk mitigation: credit scoring and ranking } \\
\text { (collateral is recommended to reduce risk, } \\
\text { so the credit rating is higher). }\end{array}$ \\
\hline 12 & PT Digital Alpha Indonesia & $\frac{\text { https://vangteman.c }}{\text { om/ }}$ & $\begin{array}{l}\text { Business model: P2P financing } \\
\text { Targets: business and consumption (short } \\
\text { term) } \\
\text { Financial transactions: virtual account } \\
\text { Risk mitigation: impose service costs } \\
\text { (operational and risk) }\end{array}$ \\
\hline 13 & PT Indo FinTek & $\begin{array}{l}\text { https://www.dompetk } \\
\text { ilat.co.id/ }\end{array}$ & $\begin{array}{l}\text { Business model: P2P financing } \\
\text { Main target: general } \\
\text { Financial transactions: virtual account } \\
\text { Risk mitigation: credit scoring and credit } \\
\text { profiling. }\end{array}$ \\
\hline 14 & PT Indonusa Bara Sejahtera & $\begin{array}{l}\text { https://www.taralite.c } \\
\text { om/ }\end{array}$ & $\begin{array}{l}\text { Business model: P2P financing } \\
\text { Main targets: general (venture capital and } \\
\text { multipurpose: labor, marriage, home } \\
\text { renovation, motor vehicle loans (KKB), other } \\
\text { multipurpose. } \\
\text { Financial transactions: virtual account } \\
\text { Risk mitigation: access to social media } \\
\text { accounts, credit scoring }\end{array}$ \\
\hline 15 & PT Dynamic Credit Asia & $\begin{array}{l}\text { http://www.dynamicc } \\
\text { redit.co.id/ }\end{array}$ & The website not active yet \\
\hline 16 & PT Fintegra Homido Indonesia & http://fintegra.co.id/ & $\begin{array}{l}\text { Business model: P2P Financing \& Equity } \\
\text { Crowdfunding } \\
\text { Primary target: MSME maritime and fisheries } \\
\text { sector } \\
\text { Financial transactions: virtual accounts, } \\
\text { direct transfers from financial agents (Banks, } \\
\text { Financing Companies, Venture Capital, } \\
\text { etc.) } \\
\text { Risk mitigation: not explained in detail }\end{array}$ \\
\hline 17 & PT Sol Mitra Fintec & http://solmitra.com/ & $\begin{array}{l}\text { Business model: Service provider liaison } \\
\text { between buyers, sellers, and financial } \\
\text { institutions in the financial supply chain } \\
\text { (Supply Chain Finance) and collaboration } \\
\text { services (Collaboration Services). P2P } \\
\text { financing through factoring } \\
\text { Primary target: general (seller, buyer, } \\
\text { financial institution). } \\
\text { Financial transactions: virtual account. } \\
\text { Risk mitigation: not explained in detail. }\end{array}$ \\
\hline 18 & PT Creative Mobile Adventure & http://kimo.co.id/ & $\begin{array}{l}\text { Business model: P2P financing } \\
\text { Primary target: retail (Tronic pulses) } \\
\text { Financial transactions: virtual account } \\
\text { Risk mitigation: not explained in detail }\end{array}$ \\
\hline 19 & PT Digital Tunai Kita & http://tunaikita.com/ & $\begin{array}{l}\text { Business model: P2P financing } \\
\text { Main target: retail } \\
\text { Financial transactions: virtual account } \\
\text { Risk mitigation: social media networks, anti- } \\
\text { fraud systems, boost limits, credit scoring } \\
\text { with artificial intelligence. }\end{array}$ \\
\hline 20 & PT Progo Puncak Group & $\begin{array}{l}\text { https://pinjamwinwin. } \\
\text { com/ }\end{array}$ & $\begin{array}{l}\text { Business model: P2P financing } \\
\text { Main targets: general (Jakarta, Bogor, } \\
\text { Depok, Tangerang, Bekasi, Bandung, }\end{array}$ \\
\hline
\end{tabular}




\begin{tabular}{|c|c|c|c|}
\hline & & & $\begin{array}{l}\text { Karawang, Semarang, Surabaya, Sidoarja, } \\
\text { Gresik, Mojokerto, and Pasuruan) } \\
\text { Financial transactions: virtual account } \\
\text { Risk mitigation: validation by a survey, credit } \\
\text { scoring, behavioral analytics, biometric } \\
\text { security, investment } \leq 2 \text { billion is borne }\end{array}$ \\
\hline 21 & PT Relasi Perdana Indonesia & $\frac{\text { http://www.relasi.co.i }}{\mathrm{d}}$ & $\begin{array}{l}\text { Main targets: general, MSMEs (Project } \\
\text { Financing, Bailout Loans, Investment Loans, } \\
\text { Receivables Financing, Non-Revolving } \\
\text { Working Capital Loans). } \\
\text { Financial transactions: virtual account } \\
\text { Risk mitigation: Collateral, }\end{array}$ \\
\hline 22 & PT iGrow Resources Indonesia & $\begin{array}{l}\text { https://www.igrow.asi } \\
\text { a/ }\end{array}$ & $\begin{array}{l}\text { Business model: P2P financing } \\
\text { Main target: farmers } \\
\text { Financial transactions: virtual account } \\
\text { Risk mitigation: surveyors conduct quality } \\
\text { assurance monitoring and reporting. }\end{array}$ \\
\hline 23 & PT Credit Indonesia & https://areditt.id/ & $\begin{array}{l}\text { Business model: P2P financing } \\
\text { Primary target: general (short term) } \\
\text { Financial transactions: virtual account } \\
\text { Risk mitigation: not mentioned in detail. }\end{array}$ \\
\hline 24 & PT Cicil Solusi Mitra Teknologi & $\frac{\mathrm{https}: / / w w w . c i c i l . c o . i}{\mathrm{~d} /}$ & $\begin{array}{l}\text { Business model: P2P financing } \\
\text { Main target: students } \\
\text { Financial transactions: virtual account } \\
\text { Risk mitigation: credit scoring }\end{array}$ \\
\hline 25 & PT Intekno Raya & $\begin{array}{l}\text { https://www.cashindo } \\
\text {.co.id/ }\end{array}$ & The website not active yet \\
\hline 26 & PT Dana Syariah & http://danasyariah.id/ & $\begin{array}{l}\text { Business model: P2P Lending (marketplace); } \\
\text { Primary Target: Property Entrepreneurs } \\
\text { Akad: Murabaha } \\
\text { Risk Mitigation: Credit Scoring }\end{array}$ \\
\hline
\end{tabular}

